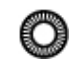

\title{
"A Meat Locker in Hebron": Meat Eating, Occupation, and Cruelty in To the End of the Land
}

Aaron Kreuter

\begin{abstract}
In this paper, I explore the connections between meat-eating, cruelty, and the Israeli/Palestinian crisis in Israeli author David Grossman's 2008 novel To the End of the Land (translated from the Hebrew in 2010 by Jessica Cohen). Using the radical vegetarian-feminist theories of Carol J. Adams, I argue that in the novel, Grossman reveals how the Israeli nationstate's treatment of the occupied Palestinian people is part and parcel of the same ideological construct that allows its citizens to consume the flesh of dead animals; if a nation can eat meat, it can dehumanize and oppress its unwanted others. In particular, I look at a pivotal moment in the novel, where the protagonist Ora's son's military unit leaves an elderly Palestinian man chained up and suffering in a Hebron meat locker; I locate this event as the most important physical space in a novel preoccupied with space, land, and physicality. I also look at another example of a Jewish author grappling with the cruelty of eating meat, the Yiddish writer Isaac Bashevis Singer's short story "The Slaughterer." Finally, I interrogate the idea, put forward by Todd Hasak-Lowy, that Grossman is less concerned with the sufferings of the Palestinian people than he is the sufferings of the stoic Israeli, forced to make compromising moral choices.
\end{abstract}

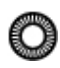

As the pithy saying often attributed to Mahatma Gandhi has it, "The greatness of a nation and its moral progress can be judged by the way its animals are treated." Though the veracity of this quote is murky, it succinctly presents the relationship between nation and animal as one based on ethics. ${ }^{1} \mathrm{~A}$ nation that treats its animals with cruelty, the equation suggests, will treat the citizens (or non-citizens) it deems undesirable with cruelty as well. One way into the question of the relationship between animal and nation-state, then, is through the concept of cruelty, particularly as it relates to the eating of meat (individual cruelty) and to military occupation (national cruelty). ${ }^{2}$ Taking this intersection of nation-state, animals, and cruelty as its starting point, this paper will offer a reading of Jewish-Israeli David Grossman's 2008 novel, To the End of the Land (translated from Hebrew in 2010 by Jessica Cohen). In a novel preoccupied with 
the effects/affects of the Israeli-Palestinian crisis, the predominance of issues of meat-eating, cruelty, and vegetarianism in the text deserves rigorous analysis. What exactly is Grossman trying to say about the relationship between the ways humans treat other humans and the ways humans treat non-human animals? In unpacking the most significant moments of meat-eating and cruelty in the novel, I will argue that Grossman reveals how the Israeli nation-state's treatment of the occupied Palestinian people is part and parcel of the same ideological construct that allows its citizens to consume the flesh of dead animals; if a nation can eat meat, it can dehumanize and oppress its unwanted others. The three distinct but related instances I will unpack in this paper are: Avram's capture and subsequent torture by the Egyptian army in the 1973 Yom Kippur War, which leads him to a strict vegetarianism; four year-old Ofer's discovery of where meat comes from and, not shielded by the rationalizations of adulthood, in unfiltered moral disgust, his own turning to fanatical vegetarianism; and finally, having grown out of his aversion to meat, Ofer's participation, as a soldier in the Israeli army, in an event of shocking cruelty, when he and his unit lock an elderly Palestinian man in a meat locker in Hebron and leave him there, naked and suffering, for almost forty-eight hours. Grossman's decision to locate this act of cruelty in a meat locker is no coincidence: cruelty towards animals, he suggests, easily translates into cruelty towards fellow humans, both of which, as Anat Pick shows, are made of vulnerable flesh and are therefore precious.

To the End of the Land is a large, encompassing work of fiction, spanning over forty years and six-hundred and fifty pages, located in Tel Aviv and Jerusalem and Jaffa and the entire north of the country. It is there, in the north, where the main characters, Ora and Avram, spend the majority of the book. To the End of the Land is a meaty novel of many things: what a national army does to its sons (and daughters), about telling stories, about raising children, about "all the minutiae, the thousands of moments and acts from which you raise a child, 
gather him into a person" (204). Rendered down to its bare bones, the novel is an intimate portrait of an Israeli woman dealing with the daily realities of living in a highly militarized country, one where your children - but especially your boys - are taken from you by the army and "nationalized" by the country's "iron boot," as Ora puts it (605). After Ora's younger son Ofer re-enlists for a thirtyday military offensive just days after being discharged from regular service, Ora decides she cannot wait around for the news of his death and goes on the hiking trip in the Galilee that she and Ofer were supposed to go on (the original Hebrew title of the novel, "Woman Escapes From the News," is, in many ways, a more fitting title). ${ }^{3}$ Instead of Ofer, Ora drags along Avram, her lost lover and the estranged father of unknowing Ofer. ${ }^{4}$ Avram was severely traumatized as a prisoner of war during the 1973 Yom Kippur War. In order not to forget Ofer as she escapes the possible news of his death, and to bring him into Avram's life for the first time, Ora narrates Ofer's entire life in painstaking detail as they hike the valleys, farmland, mountains, and towns of northern Israel. Grossman weaves the narrative in such a way that the themes under investigation here - meat-eating, military occupation, cruelty, the nation-state - come to a head in what I locate as the novel's climax, where Ora tells Avram about the weekend when Ofer's army unit left an elderly Palestinian man naked and gagged in a Hebron meat locker for forty-eight hours. As we will see, it is this incident, the Palestinian body locked in with the swinging carcasses of cows, goats, and sheep, that most clearly and damningly relates the cruelty of meat-eating to the national cruelty of military occupation.

David Grossman is one of Israel's foremost novelists and public figures. Fluent in Arabic, empathetic towards Palestinians, Grossman is seen in the Israeli cultural imaginary as, in the words of Todd Hasak-Lowy, both "a staunch leftist and a mainstream figure" (302). 5 Grossman's public persona is shadowed by the terrible irony contained in To the End of the Land: during the writing of the novel, 
Grossman's own son was killed while in the army, during the final hours of the Second Lebanon War. As Hasak-Lowy puts it, "Grossman's longstanding, unusually thoughtful, and not always fashionable arguments that Israel must act morally made the death of his son Uri almost grotesquely tragic" (303). After a period of mourning, Grossman went back and finished the novel; in a short afterward, Grossman writes that, "[a]fter we finished sitting shiva, I went back to the book. Most of it was already written. What changed, above all, was the echo of the reality in which the final draft was written" (653). This goes some way, perhaps, to explaining the novel's ending, where Ofer's fate is left tantalizingly ambiguous. Alan Mintz, in his introduction to a 2013 symposium on To the End of the Land that was reprinted in a special issue of Hebrew Studies, has this to say about the novel's publication, reception, and cultural importance: "The novel became a bestseller that was read with feverish intensity by those who could not help identifying with the anxieties of Israeli parenthood as embodied by the protagonist Ora" (285). The novel is an important book in the context of Israeli letters, and already has a strong and growing critical discourse; it is surprising, therefore, that so little attention has been paid to the recurring motifs of meat, torture, and cruelty that I will begin to unpack here. ${ }^{6}$

Carol J. Adams' The Sexual Politics of Meat, in which Adams presents a feminist-vegetarian critical theory, is an excellent source for revealing the hidden ideological architecture that allows the patriarchal practices of sexism and meatconsumption to continue unabated. The book reveals the irreducible connection between masculinity and meat eating, on "material, ideological, and symbolic lines" (6). Adams believes that the struggle against patriarchy and sexual oppression is also a struggle against meat-eating. As Adams puts it, "Meat is a symbol for what is not seen but is always there-patriarchical control of animals" (29). "Justice should not be so fragile a commodity that it cannot be extended beyond the species barrier of homo sapiens" (23), she writes. Expanding on 
Adams' groundbreaking work, I would like to propose that, in conjunction with the sexual politics of meat, we can and should also talk about the national politics of meat. In To the End of the Land, this national politics of meat is embedded in narratives of meat-eating, and its relation to military cruelty, seen in both Avram's torture as a Prisoner Of War (POW) and Ofer's treatment of the Palestinian man trapped in the Hebron meat locker. As Adams puts it, in an equation that could easily be a reading of Grossman's novel,

Meat's recognizable message includes association with the male role; its meaning recurs within a fixed gender system; the coherence it achieves as a meaningful item of food arises from patriarchal attitudes including the idea that the end justifies the means, that the objectification of other beings is a necessary part of life, and that violence can and should be masked. These are all a part of the sexual politics of meat. (26)

These are also, as it happens, part of the ideological structure of daily Israeli life, which Grossman has Ora attempt to confront.

To the End of the Land is, of course, not the first piece of literary fiction that explores issues of human/animal relationships and meat-eating through a Jewish lens. One of the foremost Yiddish writers of the twentieth century, Isaac Bashevis Singer, addresses these concerns in his short story "The Slaughterer," which relentlessly and disturbingly narrates the mental and spiritual disintegration of a ritual slaughterer. The ritual slaughterer was a role common in the Jewish communities of Eastern Europe, where meat had to be killed according to exacting religious doxa. "The Slaughterer" - originally written in Yiddish, as is most of Singer's work - is about Yoineh Meir, a reluctant ritual slaughterer in the pre-Holocaust Jewish town of Kolomir. Meir, who wanted to be the town rabbi, was instead forced into the duties of the ritual slaughterer, a role Meir only accedes to when asked by a prominent rabbi, who reminds Meir that "man may not be more compassionate than the Almighty, the Source of all compassion" 
(207). Meir, a pious Jew, takes to his new role with determined, if apprehensive, zeal, studying the texts focused on animal purity and slaughter. However, it does not take long for the job of killing animals to take its toll on Meir's sensitive constitution: "Every tremor of the slaughtered fowl was answered by a tremor in Yoineh Meir's own bowels. The killing of every beast, great or small, caused him as much pain as though he were cutting his own throat. Of all the punishments that could have been visited upon him, slaughtering was the worst" (208-209). Meir continues in his duties, and, since the ritual slaughterer is a well-paid job, his family begins to enjoy the trappings of extra spending money. Meir's condition nonetheless worsens: he stops eating meat, yearns to "escape from the material world," (209) and can no longer find solace in the holy texts, except for the Kabbalah and its promise of transcendence to a plane where "there was no death, no slaughtering, no pain, no stomachs and intestines, no hearts or lungs or livers, no membranes, no impurities" (209). Singer deftly reveals the contradictions in religiously-sanctioned killing of animals as it plays out on Meir's body and mind, showing the tension between Meir's desire to be faithful and his disgust at slaughtering animals in order to maintain the religious institutions of the town.

It is not until the weeks leading up to the High Holy Days that the animalslaughtering finally tips Meir into action. Killing large amounts of animals for the Jewish New Year and the following Day of Atonement - "Each holiday brings its own slaughter," the narrator tells us (211) - Meir starts having nightmares. Eventually, "An unfamiliar love welled up in Yoineh Meir for all that crawls and flies, breeds and swarms" (213). Meir's relentless ritual killing has brought him to what Anat Pick calls a "creaturely poetics," the belief that "[t]he creature [...] is first and foremost a living body-material, temporal, and vulnerable" (5), and therefore all life is treated as special due to the inherent vulnerability of the flesh, and so, ironically, Meir can no longer continue killing: "Until this day he had still 
hoped that he would get accustomed to slaughtering. But now he knew that if he continued for a hundred years his suffering would not cease" (213). Finally, Meir reaches his breaking point, and he lashes out at God. "I have more compassion than God Almighty," he yells, "more, more! He is a cruel God, a Man of War, a God of Vengeance. I will not serve Him. It is an abandoned world!" (214-15). (Notice the use of the word "cruel" here.) "The whole world is a slaughterhouse!" he laments, before running into the woods, where he drowns in the river (215). In the story's denouement, Meir is buried according to Jewish custom, and, in a final irony, the town immediately starts the search for a new slaughterer. Meir can turn his back on the Jewish tradition, Singer suggests, but it will continue on with or without him. Unlike To The End of the Land, where Grossman is interested in the relationship between meat-eating and nationalism, particularly Jewish nationalism as it manifests in the state of Israel, Singer explores the tensions between the killing of animals and the Jewish religion in his story. As Tadd Ruetenik puts it, "The days of overt animal sacrifices might seem to be over, but it remains that animals are still routinely, and even ritually, killed" (142). In fact, in Singer's later years he wrote quite frequently about meat-eating, cruelty, and vegetarianism. In the preface to Food for the Spirit: Vegetarianism and the World Religions, Singer writes: "When a human kills an animal for food, he is neglecting his own hunger for justice. Man prays for mercy, but is unwilling to extend it to others. Why should man then expect mercy from God? It's unfair to expect something that you are not willing to give. It is inconsistent" (i). Singer's ethical equation here is similar to Gandhi's and fits neatly into Adams's vegetarianfeminist project. Singer continues: "I can never accept inconsistency or injustice. Even if it comes from God. If there would come a voice from God saying, 'I'm against vegetarianism!' I would say, 'Well, I am for it!' This is how strongly I feel in this regard'" (i). This argument with God is exactly what Singer fictionalizes in "The Slaughterer."7 
To return to To the End of the Land, like Singer, both Avram and Ofer have bouts of intense vegetarianism in Grossman's novel, though both also eventually revert back to meat-eating. In fact, according to Israeli scholar Avidov LipskerAlbeck, all of Grossman's fiction engages in some way with what Lipsker-Albeck calls "the consumption of meat and how it is spoken about" (np). For LipskerAlbeck, the eating of meat is used by Grossman to represent the moment his young male protagonists "lose their faith in the private metaphors of the family vernacular" and venture into a world of more directly representational, nonsanitized language (np). Avram's initial revulsion to eating flesh, however, does not fit Lipsker-Albeck's paradigm, as it is a direct result of the torture he experiences as an Egyptian POW, not related to growing out of linguistic bonds of immediate family. Until his capture by the Egyptian army from his station in the Sinai Peninsula, Avram was a brilliant artist and writer brimming with ideas, creativity, and life. After his experiences in the POW prison he is a broken man, barely alive, unable to confront his past, his lost self, or to maintain human connection; one of the novel's central journeys is his return to some prior semblance of himself. The third-person omniscient narrator tells readers that it was not until his captors buried Avram alive that his will to live was totally broken. The long paragraph detailing the torture scene where the Egyptian soldiers bury Avram in a grave they made him dig himself deserves to be quoted from at length:

[T]he fact that strangers, in a strange land, are pouring earth on his face, burying him alive, throwing dirt into his eyes and mouth and killing him, and it's wrong, he wants to yell, it's a mistake, you don't even know me ... and that is when Avram lets go of his life, right at that moment he truly lets go. He had never let go when he was left in the stronghold alone for three days and three nights, nor when the soldiers put him on a truck and beat him within an inch of his life with fists and boots and rifle butts, nor when Egyptian fellahin stormed the truck on 
the way and wanted to attack him, nor in all the days and nights of interrogations and torture [...] But there, in the ugly yard next to the prison's concrete wall, with its hedges of barbed wire, and now, with the gaunt officer who took another step closer and leaned right over Avram to capture the last moment before all of Avram was covered with earth and swallowed up in it, Avram no longer wanted to live in a world where such a thing was possible, where a person stood photographing someone being buried alive, and Avram let go of his life and died. $(180-81)$

There are a number of things to point out here. The first is that Avram's capture and torture are a result of a war between nation-states, where both sides have othered and dehumanized their enemies. Second, Avram's torture is exacerbated by the fact that, instead of killing him, they play at killing him. Relatedly, and finally, it is the ability for humans to be cruel, more than the imprisonment and torture themselves, which breaks Avram.

Avram's torture leads to his initial physical aversion to meat. "You remember, there was a time when I didn't eat meat for a few years," he tells Ora after learning about Ofer's own childhood vegetarianism (303). "Of course she remembers," readers are told: "he used to gag every time he walked by a steak house or a shawarma stand. Even a fly burning in an electric bug trap nauseated him" (303). Avram's affective response to meat is clearly linked here to his own personal experiences of cruelty. As Mary Midley reminds us, and as we see again and again in the novel, "The symbolism of meat-eating is never neutral" (qtd in Adams 14). When Ofer enlists in the army, Avram once again forgoes the eating of non-human animals (he had started eating meat again "five or six" years after his release [303]). "But I'm a vegetarian now," he tells a surprised Ora: "I just felt like cleansing myself" (303). When Ofer gets taken by the Israeli military machine - the same military machine that led to Avram's torture - Avram once again stops eating meat - but why? In order keep Ofer safe? To prevent him from being 
tortured? Ora wonders the same thing: "Three years of abstinence from meat, she thinks, and every evening he crossed off one line on the wall [referring to the countdown of days left of Ofer's army service Ora encounters in Avram's bedroom]. What does that say? What is he saying to me?" (303). What it says is that the lines connecting the occupation and meat-eating are starting to come into focus. By the time we get to the meat locker in Hebron, these lines will have been fully realized.

It is impossible to read Ofer's own childhood vegetarianism without resonances of Avram's own aversion to cooked flesh. Ostensibly just another reminiscence of Ofer that Ora tells Avram, there is something much more significant happening in Ofer's twelve years of vegetarianism, from the age of four to sixteen. Ofer's discovery of where meat comes from - like Avram's torture - is given in extreme maximalist close-up, Grossman deploying all his powers of description to paint the familial scene. Ofer discovered the truth about meat-eating a few months before his fourth birthday. Ora came home to cook Ofer lunch, and he "asked [her] what was for lunch. So I told him this and that, rice, let's say, and meatballs [...]. Ofer asked me what meatballs are made of, and I mumbled something. I told him they were round balls, made of meat, and he thought about it and asked, 'Then what's meat?'" (301-02). Ora responds by saying to Ofer "that it was nothing, you know, just meat. I said it in the most casual voice: It's nothing special, it's just meat. You know, like we eat almost every day. Meat" (302). Lipsker-Albeck rightly reads Ofer's questioning as a "linguistic attempt to bring back the 'animal essence' of the cow while Ora tries to get him to continue eating meat through synecdochy [sic] that camouflages the slaughtered animal" (np). ${ }^{8}$ When, however, after further probing questions, Ora has no choice but to tell Ofer that the meat from the meatball he is about to eat comes from a cow, that the meat does not grow back, that the cow gets a "boo-boo when you took its meat out," (304) and that the cow was killed for the 
meat, Ofer reacts with total, unfiltered horror. ${ }^{9}$ Running around the house, touching everything, he screams: "You kill her? You kill a cow to take her meat? Tell me! Yes? Yes? You do that to her on purpose?" (306). Ofer completes his rude awakening by calling Ora - and by extension, the rest of meat-eating humanity - wolves. "You're like wolves!" he claims, "People like wolves! I don't want to be with you!" (306). Note the similarity between Ofer's statement and Avram's own desire to no longer be alive after his torture, a similarity that Avram himself comments on. Ora's narration then collapses from excruciating detail to all-encompassing summary: "The next morning he woke up with a high fever, and he wouldn't let us comfort him, wouldn't let us touch him, touch him with our meat hands, you see, and from that day, for twelve years, he didn't touch meat or anything that had been near meat" (308). (Significantly, in the original Hebrew version of this scene, the action, dialogue, and reflection is all presented in one long, stream-of-consciousness-like burst of language, with narrative sentences squeezed between the dialogue in italics, breaking the boundaries between the characters, the past, and the present. Moreover, quotation marks are not used at all in the Hebrew version, further muddying the narrative lines between story, action, and reflection. ${ }^{10}$ Ofer's radical vegetarianism lasts until he is sixteen, when, as Ora explains it, he starts "growing up, maturing" (308), which is another way of saying Ofer began preparing his body to be enlisted in the army, where things like vegetarianism were seen as weak and feminine.

Ofer's vegetarianism is far more than simply a personal choice. Readers are told that Ofer tried to convince the other kids at his school to forgo meat as well and that he fell in love with his music teacher when he found out she was also a vegetarian (333). Furthermore, in an important moment, we see these two competing desires - to not eat meat, and to fall in line with the national mythos of the Zionist state - as they play out on the young Ofer's body and daily life. Here is Ora describing the rigid ruthlessness with which Ofer adhered to his 
boycotting of meat and those with 'meat-hands': "The nightmarish mornings, the decontaminated, censored sandwiches she made-only after, of course, dressing him meticulously as an armed cowboy-the vegetarianism on the one hand, and that murderousness on the other, she now realizes in astonishment" (334). Ofer's obsession with dressing as a cowboy - that loaded emblem of American manifest destiny and settler-colonialism - and his strict vegetarianism perfectly embody the competing ideological frameworks pulling Ofer. As a thoughtful, sensitive child, he cannot so easily ignore where the food on his plate comes from. Ofer's horror even gives Ora her own, however fleeting, realization: And at that moment I got it. Maybe for the first time in my life I got what it means that we eat living creatures, that we kill them to eat them, and how we train ourselves not to realize that the severed leg of a chicken is sitting on our plate. And Ofer couldn't cheat himself that way, do you see? [...] He was totally exposed. Do you know what it is to be that kind of child, like that, in this shitty world? (305)

However, as a child enmeshed in the Israeli national ethos, he feels the pull towards masculine aggression, the overwhelming military hegemony, as can be seen in the cowboy costume. By the time he is sixteen, two years away from his army service, Ofer drops the vegetarianism seemingly overnight. About to enlist in the Israeli army, Ofer begins to remove himself from his empathetic feelings towards animals, to make room for the cruelty necessary for military occupation, for the reality of the Hebron meat locker.

The first hint we get of the Hebron incident is relatively early in the novel, before Ora and Avram commence their hike. "About a year ago, an eccentric old man from the village of Dura was left in a meat locker in Hebron," readers are told. "He spent almost forty-eight hours there. He did not die and may even have fully recovered. But since that day her life, her family's life, had slowly begun to unravel" (113). Note the choice of Hebron: perhaps the most symbolic city of the 
occupied West Bank, streets that were once bustling markets closed to Palestinians, whole army regiments stationed there to protect hundreds of Israeli settlers from hundreds of thousands of supposedly dangerous Arabs, whose only crime were living there." Other hints like this are dropped sparingly, but it is not for another four-hundred pages until we get the full story of "that evening in the restaurant" (502), the event so pivotal to the dissolution of Ora's marriage, and to the themes I am teasing out of the novel here. When Ofer and his regiment leave a gagged, naked, elderly Palestinian man locked in the meat locker of a "wealthy butcher" in Hebron and then forget about him for forty-eight hours forty-eight hours in which Ofer goes home on leave, celebrates Adam's birthday, and eats steak tartare - the connection between meat-eating and military occupation is forcefully made (617). Notice also that, unbeknownst to the family, Avram himself is abstaining from meat at the very moment of Adam's birthday dinner, to protect Ofer, who just locked a human being in a storage room for dead animals. It is at this juncture in the novel that Adams' radical claim (already quoted above) - "Justice should not be so fragile a commodity that it cannot be extended beyond the species barrier of homo sapiens" - becomes manifest (23). Moreover, and importantly, this is also the moment where Ora's two roles as mother - one as the mother of Ofer in particular; the other as the collective Israeli mother, nurturer and supporter of the Israeli soldier (the personal and the national, in other words) - come into direct tension. This is because Ora cannot get over, and will not let herself get over, what Ofer did to the elderly Palestinian; it is this very inability to excuse Ofer's behaviour that tears her family apart. Ora cannot understand how Ofer could forget about what he had done and continues to obsessively go back to the night at the restaurant:

She remembers her gaze being drawn to Ofer's raw meat; she missed the vegetarian Ofer. [...] what really went through Ofer's mind when he ate the steak, or during that game of bingo, and whether he honestly did not remember 
anything - after all, they had talked about occupation and hatred and had even mentioned locking up people and releasing them, and there was even something about silencing. How could it be that not a single alarm bell had sounded in him? How had he not picked up even the vaguest association between all of that and, say, an old man with his mouth gagged, trapped in a meat locker in the cellar of a house in Hebron? (508)

Furthermore, as Ora asks Ofer's friend, also in the regiment, "But how could you forget a human being? [...] Just explain to me how you can forget a human being in a meat locker for two whole days!" (618). Ora's insistent questioning of and horror at Ofer's actions push the men in the family, who have fit themselves more fully into the mindset of occupation, away from her. In particular, Ilan chastises Ora for blaming Ofer: "Yes, there was a screwup," he says to her. "It really is awful, I agree with you. But Ofer isn't to blame, get that into your head. There were twenty soldiers in that building and in the periphery. Twenty. You can't saddle this whole case on him. He wasn't the commander there, he isn't even an officer. Why do you think he has to be more righteous than everyone else?" (620). This reasoning that a soldier is not responsible for his actions, Ora comes to realize, is what the army has done to the men in her life. "But it's Ofer," she says to Ilan, "do you understand that, Ilan? It happened to us. It's our Ofer. How could Ofer, how could he?" (625).

The Hebron meat locker is perhaps the most important physical space in a novel preoccupied with space, land, and physicality. It is the novel's holy of holies, the nexus where a nation's treatment of animals and undesirables meet. ${ }^{12}$ This possible connection between animals raised for meat and Arabs/Palestinians, in fact, is foregrounded early in the novel: alone in isolation during the $1967 \mathrm{War}$, the teenaged Avram asks the teenaged Ora if she has heard "that thin little Arab woman, the one who cries" (10). "That's a person crying?" Ora asks, stunned: "I thought it was an animal" (10). Through these themes in his novel, then, 
Grossman suggests that one way to think through the relationship between nation and animal is as a barometric pressure reading of a nation's cruelty. Grossman uses themes of meat-eating in To the End of the Land to not only show how living in a militarized, exclusivist nation-state such as Israel desensitizes its citizens to the cruelty necessary to continue the occupation but to reveal how a society's treatment of their non-human Others allows, necessitates, and forecloses how that society will treat their human Others. This situation is of course magnified in a situation like Israel/Palestine, where in order to maintain a demographic majority, the Israeli government must keep millions of Palestinians without the status of citizenship; as Max Blumenthal reminds us, the Gaza strip has acted as "warehouse for a surplus population" since the expulsions of 1948 (3). Am I suggesting that any nation that eats meat and has factory farms will automatically mistreat wide swaths of their human population? Perhaps not so categorically. What I am suggesting, though, is that the same ideological blinders that allow people to wantonly consume meat can be utilized for heinous acts against those humans the state deems outside the imagined community of the nation.

So far in this paper, I have attempted to understand a particular relationship between meat-eating and cruelty as they play out in the nationstate of Israel, using To the End of the Land as my literary entry point. To enlarge the lens once more, I want to now turn to what exactly Grossman is saying about animals, the nation, and Palestinians. Does Grossman actually empathize with the Palestinian characters in the novel, or, as Todd Hasak-Lowy argues, is the book's entire thrust to actually elicit an emotional response for the suffering, stoic Israeli, forced to make difficult ethical decisions? In other words, do the animals and Palestinians of To the End of the Land exist as their own, empathetic entities, or are they merely objects to the subjects of the constantly conflicted Jewish Israeli? Hasak-Lowy describes the current mood in Israel thusly: "Though 
there remains awareness of the suffering Israel causes its national others, Israeli's focus on (and perhaps even preoccupation with) their own inexorable suffering has become a dominant cultural theme" (301). Hasak-Lowy believes that To the End of the Land should therefore be seen as an extremely representative text for what I am calling here Israel's third period. Grossman has continued in this novel to portray what it means to be a painfully sensitive person-or, more to the point, a painfully sensitive Israeli-in the same fashion he has since the mid-eighties. But now this type of character seems especially doomed, in large part because of his or her tie to the fate of the national collective. This is a novel about the intractable and thus tragic nature of the helpless Israeli. (304) ${ }^{13}$

For Hasak-Lowy, even though the novel figures and narrates Palestinian suffering and grievances, most significantly with the long early scene with Ora's Palestinian limo driver Samy, it all ends up feeding back into the novel's central trope of the suffering Israeli. He writes:

Grossman struggles mightily here to make any meaningful connections between the suffering of his Jewish-Israeli characters and their moral obligations to the national other that does not merely reaffirm their suffering. Put differently, when Grossman addresses the ethical obligations attending Israeli power he winds up transforming them back into the problem of Israeli suffering. (308)

When considering the role of meat and meat-eating in the novel, Hasak-Lowy's multivalent critiques gain further weight. Meat-eating, for Ora and Avram, and perhaps even Ofer, is not about the suffering of the animal per se, but it is entirely about the moral suffering of the human who is doing the eating.

Furthermore, Grossman's politics that shape and structure the novel are not as radical as they might seem. As Yehouda Shenhav points out in his important book-length essay Beyond The Two State Solution, Grossman's brand of liberal Zionism conforms entirely with what Shenhav calls the "1967 paradigm," 
which reinforces the myth of the Green Line and feeds the "new nostalgia" that before 1967 Israel was a just democracy, a nostalgia that occludes the fact that the colonial practices on display in the territories is a mere continuation of the policies of 1948. Shenhav cites Grossman's non-fiction book The Yellow Wind as part of this new nostalgia. According to Shenhav, The new nostalgia longs for a Jewish-Ashkenazi-secular Israel within the 1967 borders, thereby upholding a violent, distorted political model which denies the ethnic cleansing of 1948 , the military regime over the Arabs of 1948 , the state of emergency which pervaded until 1967 within the Green Line, and the Jewish takeover of Arab privately and communally owned lands. (24)

In other words, though Grossman empathizes with Palestinian suffering and is against the occupation of the West Bank and Gaza Strip, he still harbours nationalist sentiments. This is perhaps why meat-eating in To the End of the Land begins to reach towards (but then somewhat obliquely pulls back from) Anat Pick's concept of the creaturely. In the end, as close as he gets, Grossman does not - and perhaps cannot - fully enter that meat-locker in Hebron.

Ultimately, To the End of the Land allows us to trace the relationship between a nation's treatment and those it deems less than human - in this case, the Palestinians and animals bred, raised, and slaughtered for human consumption. The novel does this through its explorations of Avram's torture and subsequent aversion to meat, Ofer's ethical response to the fact of meat-eating, and to his eventual sublimation into the Israeli military, which climaxes with his unit's immoral treatment of the Hebron man. To the possible world Carol J. Adams imagines in the twentieth anniversary preface to The Sexual Politics of Meat, a world where "women walk down streets and are not harassed, stalked, or attacked," a world where "people no longer feel they need a 'sausage' in the morning," where "equality prevails," we can add a world where Palestinians (and Jewish Israelis) can move freely through a land that has been decolonized, 


\section{demilitarized, de-anthropocentrized, where the violence of meat-eating and military occupation are things of the past $(1,4)$.}

\section{Endnotes}

${ }^{1}$ For a fascinating look at Gandhi's complex thoughts on animal welfare, see McLaughlin.

${ }^{2}$ I am following the Oxford English Dictionary definition of cruelty: "The quality of being cruel; disposition to inflict suffering; delight in or indifference to the pain or misery of others; mercilessness, hard-

heartedness." For an in-depth exploration of how cruelty to animals manifests in literature, see Josephine Donovan's "Aestheticizing Animal Cruelty."

${ }^{3}$ As Patricia Storace puts it in an insightful review of the novel in The New York Review of Books, "The terrible news Ora is running away from is not only that Ofer may have been killed in battle, but that something in him may have been killed at home."

${ }^{4}$ The familial/sexual dynamics of the novel are rather complex. Ora, llan, and Avram, from the moment they met in a quarantine ward during the $1967 \mathrm{War}$ in the novel's hallucinogenic prologue, were in what could only be called a love triangle. The love triangle is abruptly dismantled when Avram is captured. Ilan and Ora get married and have a son, Adam; however, in an attempt to try and help Avram recover from his experiences of torture, Ora has sex with Avram, which leads to her second pregnancy and the birth of Ofer. Ofer grows up thinking that Ilan is his father, and Avram, who fears he is too psychologically damaged to be a father, keeps his distance from Ofer. When Ora and Avram are hiking northern Israel, therefore, the process of Ora narrating Ofer's life to Avram is one of revealing to Avram the unknown shape of his son.

${ }^{5}$ While Grossman definitely deserves this label, at the end of the essay I look closer at Hasak-Lowy's critique of Grossman's politics, especially as they play out in To the End of the Land.

${ }^{6}$ One exception to this is Avidov Lipsker-Albeck's "Oral or Textual: or, In What Sense David Grossman Is a Vegetarian?" which I look at below.

${ }^{7}$ Singer goes on to unequivocally place the eating of meat alongside other forms of human cruelty. "This is my protest against the conduct of the world," he writes: "To be a vegetarian is to disagree-to disagree with the course of things today. Nuclear power, starvation, cruelty-we must make a statement against these things. Vegetarianism is my statement. And I think it's a strong one" (ii).

${ }^{8}$ This focus on language, private familial discourse, and linguistic texture is, so far, the main area of critique in the discourse steadily growing around To the End of the Land. Lipsker-Albeck, for one, reads Ofer's piercing through the linguistic shield of meat meant for consumption as an "archaeology that works backwards, allowing Grossman's protagonists to restore the realness of archaeological language. [... ]This archaeological dream-converting language into realness-is the disturbing linguistic and moral theme that underlies all of Grossman's books, and it is manifested in the vegetarianism of his boyish heroes [. . .] who try to repent for their meat-nourished growth" (np). Similarly to Lipsker-Albeck, Nourit Melcer-Padon argues that the use of "private language" allows the novel's protagonists - Ora, Ilan, and Avram - to cohere as a group, rehabilitate Avram after his torture, and shield themselves from the possibility of Ofer's death (332). Likewise, Yael Almog investigates how the novel engages with biblical myth through linguistic play, arguing that the text "questions the limits of Israeli literature in redefining the valence of the language in which it is written as well as the ability of literary texts to reshape major conditions for their own reception: collective memory and national motifs" (231).

${ }^{9}$ Ilan, moreover, gets upset that Ora told Ofer the truth about meat, claiming that he had already known how Ofer would respond once he found out. Ilan knew Ofer would ask about meat one day soon, once he had "saw what kind of boy he was, really" (302).

${ }^{10}$ For a thorough reading of this scene in the original Hebrew, especially the use of conjunctive grammar, see Nourit Melcer-Padon, pp. 336-338. These telling differences between Grossman's Hebrew version and Cohen's English translation show how important the linguistic decisions translators must make are, and how they impact the texts. 
${ }^{11}$ For a firsthand account of how life in Hebron has been for Palestinians since Jewish settler Baruch Goldstein killed twenty-nine Palestinians at the Tomb of the Patriarchs, see Einat Fishbain's "A City of Devastation: Hebron 20 Years After the Massacre."

12 It is interesting to compare the elderly Palestinian man locked in the meat locker to the clandestine night hospital located in a school that Ora visits early in the novel, where illegal Palestinians are medically treated. Both buildings serve civic functions, one for the production of consumable animal flesh, the other for the education of youth, yet both here are used for other purposes: the illegal confinement of an innocent elderly man (cruelty), and as a space for healing the undocumented, the unwanted, the dehumanized (kindness).

${ }^{13}$ Significantly, Hasak-Lowy does not believe the novel has a climax: "What is the climax of To the End of the Land?" he asks. "Can this novel be said to properly have a climax?" (305). As I mentioned in this paper's introduction, I locate Ora's narration of the scene at the restaurant as the hidden climax of the novel, since it not only reveals the reason for the disintegration of her marriage and family but completes Ofer's transformation from a committed vegetarian to a soldier who carries out the occupation through the dehumanziation of West Bank Palestinians. While Hasak-Lowy claims that Avram is the novel's character with the "great transformation," which is true, I would like to suggest that Ofer's sublimation into the collective Israeli military machine is just as great - and just as, if not more, tragic. 
(6)

\section{Works Cited}

Adams, Carol J. The Sexual Politics of Meat: A Feminist-Vegetarian Critical Theory. Twentieth Anniversary Ed, Continuum, 2010.

Almog, Yael. "Public Rituals: Grasping Myth in David Grossman's To the End of the Land." Contemporary Judaism and Politics, vol. 6, no. 2, 2016, pp. 231-250.

Blumenthal, Max. The 51 Day War: Ruin and Resistance in Gaza. Nation Books, 2015. "Cruelty, n." The Oxford English Dictionary. OED Online.

http://www.oed.com.ezproxy.library.yorku.ca/view/Entry/45169? redirectedFrom=crue Ity\&. n.d.

Donovan, Josephine. "Aestheticizing Animal Cruelty." College Literature, vol. 38, no. 4, 2011, pp. 202-217. JSTOR. Accessed 28 May 2018.

Grossman, David. To the End of the Land. Translated by Jessica Cohen, Emblem, 2011.

Fishbain, Einat. "A City of Devastation: Hebron 20 Years After the Massacre." 972 Magazine,

25 Feb 2014. https://972mag.com/a-city-of-devastation-hebron-20-years-afterthe-massacre/87714/. n.d.

Hasak-Lowy, Todd. "Grossman after 2000: An Ambivalent Complaint in Nine Parts." Hebrew Studies, vol. 54, 2013, pp. 299-309. JSTOR. Accessed 3 Aug 2015.

Lipsker-Albeck, Avidov. "Oral or Textual: or, In What Sense David Grossman Is a Vegetarian?" Ot: A Journal for Literature and Theory, vol. 2, 2012, pp. 205-217 (Hebrew), translated by Avidov Lipsker-Albeck, academia.edu.

McLaughlin, Ryan P. "Non-Violence And Nonhumans: Foundations For Animal Welfare in the Thought of Mohandas Gandhi and Albert Schweitzer." Journal of Religious Ethics, vol. $\quad 40$, no. 4, 2012, pp. 678-704.

Melcer-Padon, Nourit. "Fending Off Pain: David Grossman's Labyrinth of Language." Knowledge and Pain, edited by Esther Cohen, et al., Brill, 2012, pp. 331-352. 
Mintz, Alan. "David Grossman's To The End of The Land: A Symposium." Hebrew Studies, vol. 54,2013, pp. 285-286.

Pick, Anat. Creaturely Poetics: Animality and Vulnerability in Literature and Film. Columbia UP, 2011.

Ruetenik, Radd. "Violence, Sacrifice, and Flesh Eating in Judeo-Christian Tradition." Contagion: Journal of Violence, Mimesis, and Culture, vol. 22, 2015, pp. 141-151.

Singer, Isaac Bashevis. Preface. Food For the Spirit: Vegetarianism and the World Religions, by Steven Rosen, Bala Books, 1990, pp.1-14.

---. "The Slaughterer." Translated by Mirra Ginsburg, The Collected Stories, Farrar, Straus, Giroux, 1996. pp. 207-216.

Shenhav, Yehuda. Beyond the Two State Solution: A Jewish Political Essay. Polity Press, 2012.

Storace, Patricia. "A Woman Running From the News." Review of To the End of the Land. The New York Review of Books, 13 Oct 2011.

Aaron Kreuter is a SSHRC-funded Ph.D. candidate and a course instructor in the English department at York University. His dissertation explores Jewish North American fiction that takes Israel/Palestine as its subject matter. He is the author of the poetry collection Arguments for Lawn Chairs as well as the forthcoming short story collection You and Me, Belonging. 